\title{
Intraoral Appliance
}

National Cancer Institute

\section{Source}

National Cancer Institute. Intraoral Appliance. NCI Thesaurus. Code C62543.

Any device worn within the mouth that can be removed and is not primarily designed to replace teeth. 